\title{
Eco-epidemiological study on sandflies and environmental aspects related to the transmission of leishmaniasis in a municipality of Minas Gerais, Brazil, 2015-2016
}

[Estudo eco-epidemiológico da fauna flebotomínica e dos aspectos ambientais relacionados à transmissão das leishmanioses em um município de Minas Gerais, Brasil, 2015 - 2016] E .Michalsky ${ }^{2}$, F.O. Lara-Silva ${ }^{2}$, A.G.M. Souza ${ }^{2}$, C.L. Fortes-Dias ${ }^{4}$, M.H.F. Morais ${ }^{3}$, R.R. Nicolino ${ }^{1}$, D.F.M. Soares ${ }^{1}$

\author{
${ }^{1}$ Escola de Veterinária - Universidade Federal de Minas Gerais - Belo Horizonte, MG \\ ${ }^{2}$ Instituto René Rachou - Fundação Oswaldo Cruz - Belo Horizonte, MG \\ ${ }^{3}$ Secretaria Municipal de Saúde - Prefeitura de Belo Horizonte - Belo Horizonte, MG \\ ${ }^{4}$ Fundação Ezequiel Dias - Belo Horizonte, MG
}

\begin{abstract}
The aim of this study was to evaluate Leishmania vectors and investigate the environmental and climatic characteristics related to their transmission. This was a prospective eco-epidemiological study involving the systematic collection of sandflies and a canine serological survey in areas of municipality in Brazil. Blood samples from 1,752 dogs were examined to test for canine visceral leishmaniasis (VL). An entomological evaluation was carried out using 24 light traps in the peridomicile and intradomicile areas of 12 households for 12 months. Climate variables were analyzed using a simple Spearman correlation and a spatial analysis via the fuzzy logic method and K function. The prevalence rate of canine VL was $4.1 \%$ and $7.1 \%$ in the two areas that were studied, respectively. The entomological study resulted in the capture of 431 sandflies. Most (74\%) of the specimens were captured in the peridomiciliary area, and $5.6 \%$ of the samples that were analyzed using molecular biology were positive for Leishmania spp. In particular, Leishmania infantum was found in $100 \%$ of the positive samples. The spatial analysis showed that one particular area presented a higher concentration of high-density overlapping points of Lutzomyia longipalpis and seropositive dog populations, indicating a higher risk of the concomitant occurrence of both events. The results show that a parasite-reservoir-vector interface is active in the studied areas.
\end{abstract}

Keywords: Leishmania infantum, visceral Leishmaniasis, Lutzomyia, sandflies, public health

\section{RESUMO}

Objetivou-se avaliar a fauna vetorial e os aspectos ambientais e climáticos relacionados à transmissão das leishmanioses. Foi realizado um estudo eco-epidemiológico prospectivo de coleta sistemática de flebotomíneos e inquérito censitário sorológico canino em áreas de um município do Brasil. Para determinar a taxa de prevalência de LVC, foram examinadas amostras de sangue de 1752 cães. Na avaliação entomológica, foram instaladas 24 armadilhas luminosas em 12 residências distribuídas, instaladas no ambiente de peridomicílio e intradomicílio durante 12 meses. Para análise dos aspectos climáticos, utilizou-se a correlação simples de Spearman e para análise espacial foram utilizadas a Lógica Fuzzy e a Função K. A taxa de prevalência em cães foi de $4,1 \%$ e 7,1\%. No estudo entomológico, foram capturados 431 flebotomíneos. A maior parte $(74 \%)$ dos espécimes foi capturada no peridomicílio. Em relação à infecção natural, 5,6 \% das amostras analisadas por biologia molecular apresentaram positividade à infecção por Leishmania spp.. Em 100\% das amostras positivas, encontrou-se infecção por Leishmania infantum. Na análise espacial uma Área apresentou maior concentração de pontos de sobreposição de alta densidade de Lutzomyia longipalpis e cães sororreagentes, indicando maior risco na ocorrência concomitante dos dois eventos. Os resultados mostram que a interface parasito-reservatório-vetor está ativa nas áreas estudadas.

Palavras-chave: Leishmania infantum, Leishmaniose visceral, Lutzomyia, saúde pública

Recebido em 20 de novembro de 2018

Aceito em 27 de março de 2019

E-mail: laizabonela@hotmail.com 


\section{INTRODUCTION}

Leishmaniases are a group of diseases caused by protozoa of the Leishmania genus (World..., 1988), which are present in five continents and endemic in 98 countries (Alvar et al., 2012). The WHO estimates that 350 million people are at a risk of developing clinical leishmaniasis that can be subdivided into visceral leishmaniasis (VL) and cutaneous leishmaniasis (CL) (World..., 2016). American CL (ACL), a common infectious disease that affects human beings, is caused by several species of protozoa of the genus Leishmania (Ross, 1903). These organisms have several natural reservoirs, such as rodents, marsupials, and wild canids (Brasil, 2009). American VL (AVL) is a severe, neglected disease caused by Leishmania (Le.) (Leishmania) infantum (synonym Le. infantum chagasi) in Brazil, and its main reservoir, in domestic and peridomiciliary environments, is the domestic dog (Canis familiaris). The presence of both the vector and reservoir contributes strongly to the maintenance cycle of this disease (Lainson and Rangel, 2005).

Leishmaniasis vectors are insects in the order Diptera, family Psychodidae, and subfamily Phlebotominae. There are more than 400 identified species of Lutzomyia, but only around 40 are involved in the transmission of Leishmania (Rangel and Lainson, 2003). In Brazil, the species of sandflies that are considered ACL vectors are Lutzomyia (Lu.) (Nyssomyia) intermedia (Lutz and Neiva, 1912), Lu. (Nyssomyia) whitmani (Antunes and Coutinho, 1939), Lu. (Pintomyia) fisheri (Pinto, 1926), Lu. (Pintomyia) pessoai (Coutinho and Barreto, 1940), Lu. migonei (França, 1920), and Lu. (Nyssomyia) flaviscutellata (Mangabeira, 1942) (Rangel and Lainson, 2003); other VL vectors include Lu. (Lutzomyia) longipalpis (Deane and Deane, 1962), and Lu. (Lutzomyia) cruzi (Galati et al., 1996).

The aim of this study, which was the first entomological study conducted in Juatuba, Minas Gerais was to evaluate Leishmania vectors and to carry out a canine serological survey. The research was carried out in a municipality in Brazil, which already has registered autochthonous human cases of ACL and AVL. Previous studies have found a high prevalence of canine VL in this municipality, especially in areas with a high population density of dogs (Borges et al., 2014; Lopes et al., 2016).

\section{MATERIALS AND METHODS}

The current project was approved by the Research Ethics Committee (CAAE 38073114.6.0000.5149) and the Ethics Committee on Animal Use (protocol 92/2014) of the Federal University of Minas Gerais. This project included a prospective, longitudinal, ecoepidemiological study conducted on sandflies and a canine serological survey for VL in the city of Juatuba, Minas Gerais, Brazil conducted between 2015 and 2016. Juatuba is in the central area of the state of Minas Gerais, located $45 \mathrm{~km}$ from Belo Horizonte. The environmental condition of this municipality is a determinant for the survival of the vector.

Two areas were non-randomly selected based on three inclusion criteria: (1) a high prevalence of canine VL (Borges et al., 2014; Lopes et al., 2016), (2) a history of human cases of ACL and AVL, and (3) similar socioeconomic, environmental, and ecological characteristics, such as the presence of animals, fruit trees, and accumulated organic matter. The canine serological survey and systematic capture of sandflies were carried out in these areas.

The canine survey was carried out in the first half of 2015 in all households in Areas 1 and 2 after the presence of dogs was confirmed. Blood samples were collected and processed as a standardized procedure. Serological diagnostic methods were used to test the sera samples as recommended by the Brazilian Ministry of Health. Rapid tests (TR-DPP®, BioManguinhos/Fiocruz, Brazil) were used as blood screening tests, and enzyme-linked immunosorbent assays (ELISA) were used to confirm the canine VL diagnosis. The inclusion criteria to select dogs for blood collection were as follows: (1) dogs with tutors, (2) dogs at a minimum age of 4 months, and (3) an informed consent form signed by the dog owner. Further, the prevalence coefficient of canine VL in the city was calculated (Medronho et al., 2009).

Twelve households were selected-six in Area 1 and six in Area 2-based on epidemiological and environmental aspects, using the following criteria: (1) a history of canine positivity for VL 
and (2) favorable environmental conditions for the presence of sandflies. Sandflies were captured using 24 Hoover-Pugedo (HP) light traps (Pugedo, 2005). The collections took place in 12 households during three consecutive nights in the last week of each month over a total period of 12 months. Two light traps were placed in each household: one was placed in the intradomicile area and the other, in the peridomicile area (near the animals, fruit trees, and organic matter). The traps were exposed from 5:00 p.m. to 8:00 a.m., totaling to 15 hours of uninterrupted collection. The number of sandfly specimens collected was a measure of the monthly population density.

Sandflies of both sexes were identified based on the Young and Duncan classification (Young and Duncan, 1994), using specific descriptions, taxonomic keys, and comparisons with specimens stored in the sandfly collection of the René Rachou Institute/Fiocruz, Brazil. Specimens whose species could not be identified due to missing or incomplete taxonomic characteristics were identified in terms of gender. Only males from the species Lutzomyia sallesi and Lutzomyia cortelezzii were found while the females of these two species were identified as cortelezzii complex due to the morphological similarity between them (Galati et al., 1989).

Deoxyribonucleic acid (DNA) was extracted from individual female sandflies to detect the presence of Leishmania spp. Leishmania DNA was detected using the Leishmania nested polymerase chain reaction (LnPCR) technique, which specifically targets the SSUrRNA gene (Van Eys et al., 1992). The total DNA extracted from the female sandflies was amplified using Kinetoplastida-specific primers. The second reaction, involving a specific pair of primers for Leishmania, yielded a 353-bp fragment in positive samples. This could be visualized using ultraviolet light after electrophoresis on $2 \%$ agarose gel and staining with ethidium bromide. Negative control samples (without DNA) and DNA-positive samples extracted from $L e$. infantum (MHOM/BR74/PP75) were also created. The LnPCR-amplified fragments were purified using a commercial kit (QIAquick Gel Extraction Kit; QIAGEN), and DNA sequencing was performed in both directions using a kit (BigDye Terminator v3.1 Cycle) and a Megabace (GE HealthCare).
Sequencing and alignment editing of Leishmania DNA sequences (Le. braziliensis [M80292.1], Le. amazonensis [M80293.1] and Le. chagasi [M81430.1]), which are stored in the GenBank database, were performed using the Basic Local Alignment Search Tool (BLAST) software (https://blast.ncbi.nlm.nih.gov/Blast.cgi). The natural infection rate of the Leishmania spp. in the captured females was calculated using the following formula:

$$
\begin{aligned}
& \text { Minimum infection rate } \\
& =\frac{\text { Number of positive tools } x 100}{\text { Total number of specimens tested }}
\end{aligned}
$$

Monthly climate data, including temperature $\left({ }^{\circ} \mathrm{C}\right)$, relative air humidity $(\%)$, and rainfall $\left(\mathrm{mm}^{3}\right)$, during the study period, were obtained from the nearest Meteorological District $\left(5^{\text {th }}\right.$ District of the Brazilian Institute of Meteorology, Belo Horizonte, MG) (Instituto..., 2016). Spearman's non-parametric analysis was used to evaluate the effects of climate variables on the population density of sandflies. Using the GraphPad Prism 6 software, the Spearman correlation coefficients (r) and p-values were calculated for each pair of variables with a confidence level of $95 \%$.

All the households included in the canine serological survey and the capture of sandflies were georeferenced using a global positioning system (GPS) and referenced using a universal transverse Mercator projection. Subsequently, the intra- and peridomicile densities were analyzed to ascertain the abundance of the VL vector (Lu. Longipalpis). This was then correlated with the canine VL positivity density at each of the 12 capture points using an overlay analysis technique of two layers of data called the fuzzy logic method (Spatial Analyst Toolbox). The K Function was performed using the ArcGIS 10.4 geoprocessing package (Spatial Statistics Toolbox), with input data of the actual geographical position of each canine VL case. A separate analysis was performed in each area so that one region did not influence the other, with 999 permutations of the expected $\mathrm{K}$ function.

\section{RESULTS}

The canine serological survey was carried out in two areas over a 6-month period. In total 1,752 dogs were tested: 1,163 in Area 1 and 589 in 
Area 2. The prevalence of canine VL in Areas 1 and 2 was $4.1 \%$ (95\% confidence intervals: $3.27-$ $-5.91)$ and $7.1 \%$ (95\% confidence intervals: 5.25-9.59), respectively. The prevalence was higher in Area 2 than in Area $1(\mathrm{P}=0.007)$. During the study period, 431 sandflies were captured in both areas collectively; 298 (69.1\%) were males (Table 1). The total male:female ratio was around 2:1. Males were predominant among the captured species, especially among $L u$. longipalpis, a proven AVL vector, with a ratio of 8:1. Among the species that were captured, 11 were of the genus Lutzomyia, which includes the species responsible for leishmaniases, and three were of the genus Brumptomyia, which does not have medical importance. Among the species of the Lutzomyia genus, four are involved in the transmission of leishmaniases: Lu. intermedia, $L u$. pessoai, and Lu. whitmani (ACL vectors), as well as Lu. longipalpis (AVL vector).

Table 1. Distribution of phlebotomines sandflies captured according to species and gender using HooverPugedo-like light traps in Juatuba, Minas Gerais, Brazil, from April 2015 through March 2016

\begin{tabular}{lllll}
\hline \multirow{2}{*}{ Species of sandfly } & \multicolumn{2}{l}{ Number of sandflies } & \multirow{2}{*}{ Relative percentage (\%) } \\
\hline Brumptomyia spp. & Males & Females & Total & \\
cortelezzii complex & 7 & 3 & 10 & 2.3 \\
Lutzomyia spp. & 0 & 45 & 45 & 10.4 \\
Total & 291 & 85 & 376 & 87.2 \\
\hline
\end{tabular}

Of all the captured sandflies, $74 \%$ (319) were found in the peridomicile area while $26 \%$ (112) were in the intradomicile area, and most males were captured in the peridomicile area $(\mathrm{P}<$ 0.001). With specific regard to Lu. longipalpis, the number of males found in the peridomicile area was significantly higher than the number of females $(88.2 \%$ vs. $17.8 \%$; $\mathrm{P}=0.007)$. Regarding the population found in each area, Area 1 yielded $26.9 \%$ (116) of all the captured specimens while Area 2 yielded $73.1 \%$ (315), constituting a significant difference $(\mathrm{P}=0.003)$. The sandflies were predominantly captured in the peridomiciliary environment in both areas: 66.4\% (77) in Area 1 and 77.2\% (245) in Area 2.
The sandflies that were used to analyze the natural infection rate were captured on the third night of each collection period. In total, 91 females were used: two in the genus Brumptomyia and 89 in the genus Lutzomyia. DNA detection was performed on the 89 Lutzomyia specimens since the genus Brumptomyia has no medical importance. Leishmania spp. DNA was detected in five samples (5.6\%): two from the cortelezzii complex, two from $L u$. lenti, and one from $L u$. longipalpis. The 353-bp fragments were identified using the LnPCR technique (Figure 1).

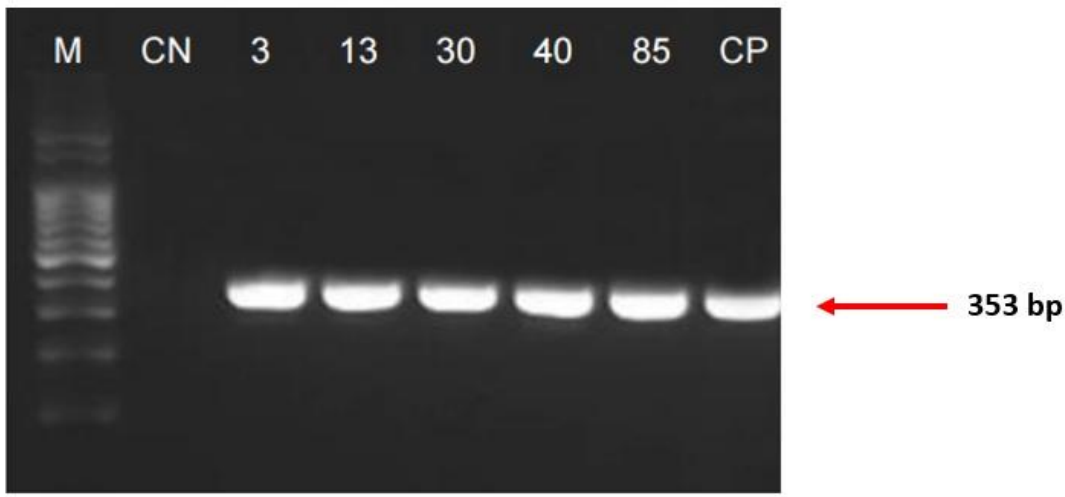

Figure 1. Amplified DNA products of Leishmania spp. in female sandflies collected in Juatuba, Minas Gerais using generic primers for Leishmania spp. (SSUrRNA). The fragments were visualized using $2 \%$ agarose gel electrophoresis and ethidium bromide staining. Lanes: M-100bp DNA ladder; CNnegative control (without DNA); positive samples-3, 13, 30, 40, and 85; CP-positive control (Leishmania chagasi; MHOM/BR/PP75). 
The identities of the species found in the sandflies were confirmed by alignment with DNA sequences of positive Leishmania spp. samples. The presence of Le. infantum DNA was confirmed in $100 \%$ of the positive samples. The
Le. infantum natural infection rate was $5.3 \%$ in sandflies of the cortelezzii complex, $8.7 \%$ in $\mathrm{Lu}$. Lenti sandflies, and $10 \%$ in Lu. longipalpis sandflies (Table 2).

Table 2. Detection of Leishmania infantum DNA (SSUrRNA) in phlebotomine sandflies species of cortelezzii complex, Lu. lenti and Lu. longipalpis captured in Juatuba, Minas Gerais, Brazil, between 2015 and 2016

\begin{tabular}{|c|c|c|c|c|c|}
\hline $\begin{array}{l}\text { Phlebotomine } \\
\text { species }\end{array}$ & sandfly & $\begin{array}{l}\text { Number of } \\
\text { specimens } \\
\text { examined } \\
\text { using PCR }\end{array}$ & $\begin{array}{l}\text { Number of } \\
\text { positive } \\
\text { specimens }\end{array}$ & Leishmania species & $\begin{array}{l}\text { Natural } \\
\text { infection } \\
\text { rate }(\%)\end{array}$ \\
\hline cortelezzii complex & & 38 & 2 & Le. infantum & 5.3 \\
\hline Lu. Lenti & & 23 & 2 & Le. infantum & 8.7 \\
\hline Lu. Longipalpis & & 10 & 1 & Le. infantum & 10 \\
\hline Other species & & 18 & 0 & - & - \\
\hline Total & & 89 & 5 & - & 5.6 \\
\hline
\end{tabular}

Lu = Lutzomyia $;$ Le = Leishmania

The areas with a greater risk for canine and human transmission of leishmaniasis were established within the studied areas using fuzzy logic analyses. These areas were characterized by a high prevalence of canine VL cases associated with a high vector density ( $L u$. Longipalpis). Areas of high overlap between both events within the surveyed areas were defined as areas with a greater possibility for both phenomena to occur or as areas with a greater risk of canine VL and human VL transmission. Area 1 had three points of "high overlap" areas, and one more centralized point of "very high" probability of the concomitant occurrence of both events: high vector density and seropositive dogs. In Area 2, there was a higher concentration of points at which both events overlapped than in Area 1, with a consequent greater number of "very high" probability areas for the concomitant occurrence of high densities of Lu. longipalpis and seropositive dogs (Figure 3).

A cluster analysis was performed using the $\mathrm{K}$ Function to verify the agglomeration of seropositive dogs in the area. Area 1 showed cases agglomerated within a radius of 450 meters, without significance after this distance (Figure 4A) while Area 2 showed cases agglomerated within a radius of 170 meters (Figure 4B).
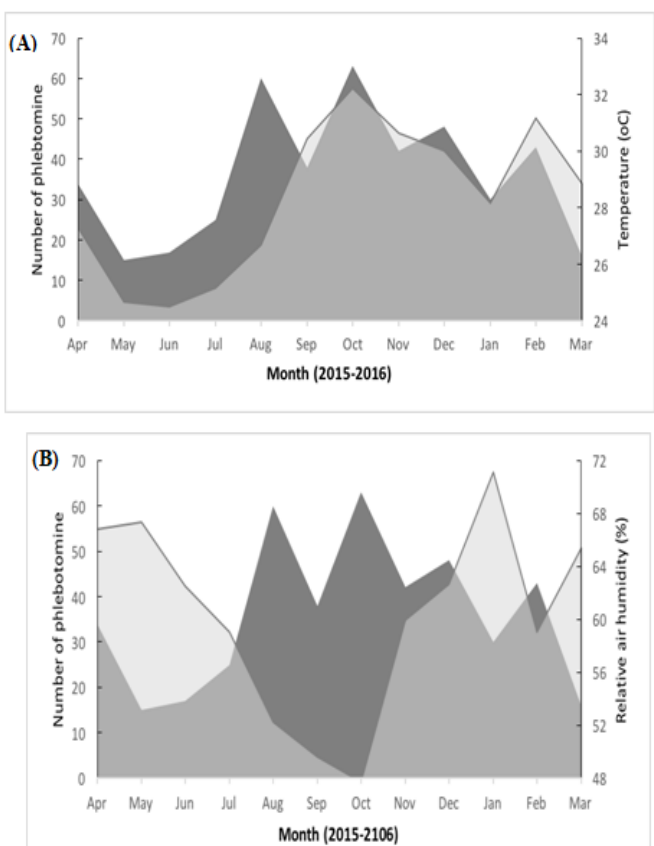

Figure 2. Climate factors that were correlated with the monthly population density of sandflies from April 2015 to March 2016 in Areas 1 and 2 in Juatuba, Minas Gerais, Brazil. A) Average monthly temperature rates. B) Relative air humidity rates. The population density of sandflies is represented in dark gray and the respective climate variable in light gray. 


\section{Gomes et al.}

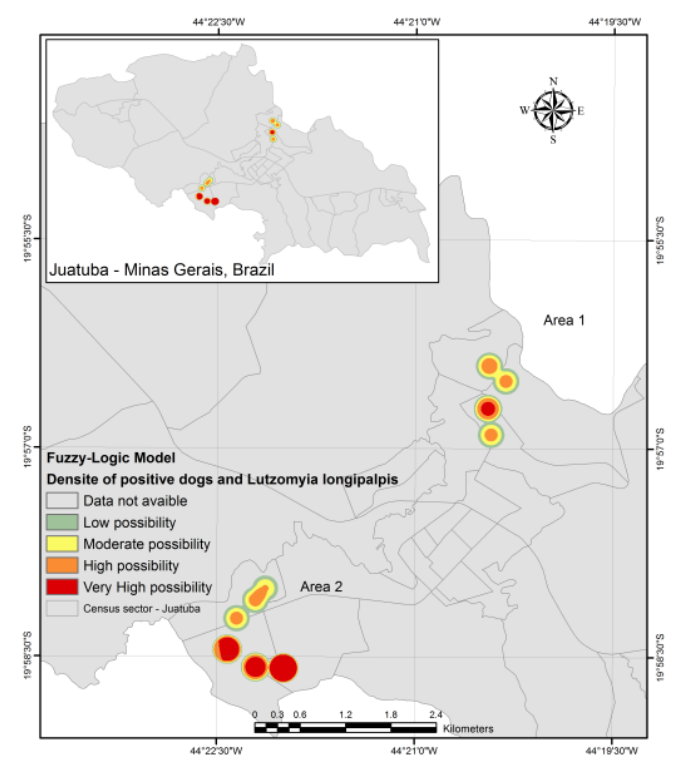

Figure 3. Map of survey Areas 1 and 2 using fuzzy logic to predict overlapping areas in Juatuba, Brazil. (Unmarked areas in the map were not researched).

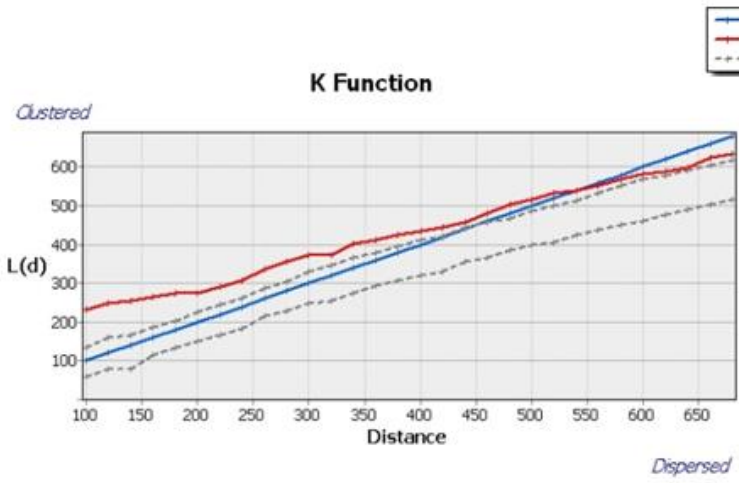

(A)
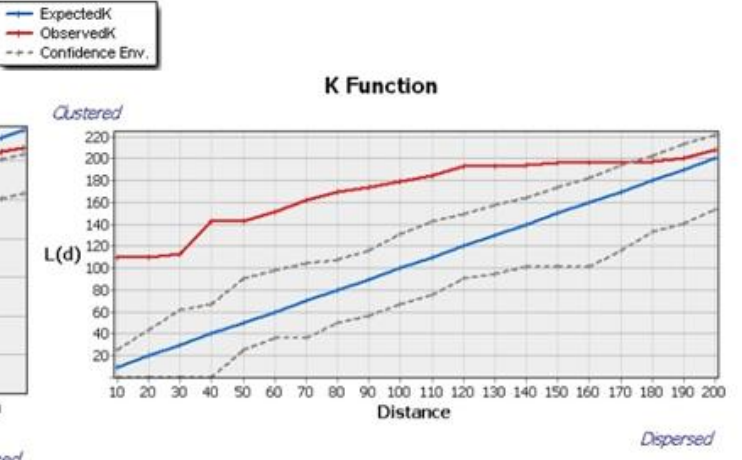

(B)

Figure 4. Function K graph showing the significance of the presence of clusters among seropositive dogs in the study area in Juatuba, Brazil. A) Area 1. B) Area 2.

\section{DISCUSSION}

The results of the evaluation of the prevalence rate of canine VL in Areas 1 and 2 were $4.1 \%$ and $7.1 \%$, respectively. These values are in agreement with the rates found in the literature for endemic areas, although they were higher than the values reported by Lara-Silva et al. (2015) and lower than the values reported by Dias et al. (2011). A study by Borges et al. (2014) in the municipality of Juatuba, Minas Gerais found an average prevalence of $10.6 \%$. Although the selection criteria for Areas 1 and 2 were similar, there was a significant difference in canine VL prevalence between them, perhaps because Area 2 had a higher presence of risk factors for VL, such as vegetation, tree roots and trunks, and organic matter in the soil (CamargoNeves et al., 2001). This may also explain the higher vector density found in this area that was significantly higher when compared to in Area 1. Furthermore, five female specimens that showed a positive natural Le. infantum infection were found in Area 2.

During the study period, 431 sandflies comprising 14 different species were captured. Similar to other studies, most were found in the peridomiciliary environment (Rêgo et al., 2014; Lana et al., 2015). The overall ratio of males to 
females was $2: 1$, which was similar to other entomological studies (Michalsky et al., 2009; Dias et al., 2011; Lana et al., 2015; Lara-Silva et al., 2015); however, this differed from the results of Rêgo et al. (2014), who reported a higher number of females than males. Among the captured specimens, four species are involved in the transmission of leishmaniasis: Lu. whitmani, $\mathrm{Lu}$ pessoai, $\mathrm{Lu}$. intermedia (ACL vectors), and $\mathrm{Lu}$. longipalpis (AVL vector) (Rangel and Lainson, 2003).

In the studied areas, Lu. longipalpis was the most abundant species, with males being predominant, in peridomiciliary and intradomicile environments; this was similar to the findings of studies carried out in regions near Juatuba, Minas Gerais (Lara-Silva et al., 2015; Vianna et al., 2016). The percentage found in the intradomicile environment was lower than what was found by Lopes (2014). However, even in smaller numbers, these data showed that the number of sandflies captured in intradomicile areas was relevant from an epidemiological perspective since the presence of Lu. longipalpis inside households can facilitate VL transmission. Many authors have found $\mathrm{Lu}$. longipalpis in greater abundance in the peridomiciliary environment (Missawa and Dias, 2007; Michalsky et al., 2009; and Lara-Silva et al., 2015), with the exceptions of Dias et al. (2011) and Rêgo et al. (2014). In the present study, the Le. infantum natural infection rate in $\mathrm{Lu}$. longipalpis was $10 \%$ lower than that found by Lara-Silva et al. (2015), and higher than that reported by Michalsky et al. (2009). The rate of Leishmania infection within this vector is considered low in nature $(0.2 \%$ to $2 \%$ ), even in areas endemic for VL (Michalsky et al., 2009).

The second most abundant vector species was $\mathrm{Lu}$. lenti, which is usually present in areas of Cerrado where there is a high density of domestic animals, mainly chickens (Galati et al., 1996). A similar result was found in a municipality with environmental and socioeconomic characteristics similar to those of the studied areas (Lana et al., 2015). Although Brazil et al. (1997) affirmed that Lu. lenti is refractory to Leishmania infection, this research verified a $L e$. infantum natural infection rate of $8.6 \%$ in $\mathrm{Lu}$. lenti. Other studies have also found Le. infantum infection in this species, reporting higher results than in the present study (Lana et al., 2015).

In the present study, the species in the cortelezzii complex had higher infection rates $(5.2 \%)$, with two positive samples for Le. infantum. Other studies have also found infection in this species, with higher values than those found in the present research (Lara-Silva, 2015). New ACL cases are reported annually in Juatuba, Minas Gerais and coincidentally, the ACL vector $L u$. whitmani was the most abundant, which makes the control or monitoring of this vector relevant. The species $L u$. pessoai represented $5 \%$ of the sandflies captured in this study, and Leishmania DNA was not detected in any of these specimens. Although studies from the 1940s have pointed to $L u$. pessoai as a probable ACL vector (Luz et al., 2001), this finding was not confirmed in the present study.

Of the species known as leishmaniasis transmitters, a low percentage of Lu. intermedia was found, which was similar to the findings of studies by Lara-Silva et al. (2015) and Dias et al. (2011) and contradictory to the findings of Lana et al. (2015). Although Lu. intermedia was found in very low numbers in the present study, this species has anthropophilic characteristics and is the most adaptive among sandfly species to many types of environments, including the synanthropic environment. Thus, it has an important epidemiological role (Luz et al., 2001)

Concerning climate factors and their correlation with vector density, more vectors were found in periods of higher average temperatures (significant positive correlation). However, periods of higher relative humidity resulted in lower vector density. According to the Brazilian Ministry of Health, the period of the greatest VL transmissibility is during and shortly after the rainy season, when an increased population density of the insect is predicted (Brasil, 2009). Thus, the present study differed from most studies because we found that vector density was the highest in the period of the highest rainfall, when the relative humidity and average temperature are normally high (Dias et al., 2011; Rêgo et al., 2014; Lana et al., 2015).

Regarding the spatial analysis, the fuzzy logic method allowed us to verify the high probability 
of overlapping high densities of seropositive dog and $\mathrm{Lu}$. longipalpis populations in Area 2. The differences between Areas 1 and 2 in this regard may have been due to differential environmental characteristics between households with the highest vector density and those with the lowest vector density. The analysis of the $\mathrm{K}$ function showed that Area 2 had a significant agglomeration of canine VL cases within a radius of approximately 170 meters. Outside this radius, there was no significant agglomeration of canine VL cases since the $\mathrm{K}$ function value was above the expected limit. This result is close to what was found by Ursine et al. (2016), who also used the $\mathrm{K}$ function to demonstrate the agglomeration of canine VL cases and found a significant result within a radius of around 70 meters. In Area 1, the VL cases showed a significant agglomeration pattern within a radius of about 450 meters. This difference may be attributable to the specific geographical and environmental characteristics of each area. It was observed that Area 1 was more urban, and the households were close to one another, whereas in Area 2, the households were naturally more spaced apart. This finding is similar to that of a study by Camargo-Neves et al. (2001), which showed great variability in the presence of sandflies among households within the municipality, as well as a non-homogeneous VL transmission in the studied area.

Although it was not an objective of this study, we observed environmental differences between the studied areas. These differential aspects that included the diversity of the animal species in the peridomicile area, soil type, and the amount of organic matter could be among the predominant factors responsible for the occurrence of high vector density in Area 2. Some of these characteristics have already been identified as risk factors for VL in earlier studies conducted in Brazil (Teodoro et al., 1999; Camargo-Neves et al., 2001). Therefore, focal control and preventive actions should be directed toward VL at specific points in Area 2; whereas in Area 1, the municipality must develop broad and diffuse preventive and control actions to reduce the occurrence of the disease in all geographical areas.

In an epidemiological study, the identification of the vector species, knowledge of its biology, and determination of the natural infection rate, especially in endemic areas, are fundamental to understanding the disease's transmission chain. Entomological results allow epidemiologists to monitor vector behavior in the studied areas, providing the necessary information to guide and effectively implement preventive measures and to improve community health (Lopes, 2014). Environmental management is one important possible preventive control measure since this method was effective in reducing the population density of Lu. longipalpis in a recent study in Brazil (Lara-Silva et al., 2017).

From a public health perspective, the presence of a group of epidemiological risk factors for VL in a municipality that is placed in the "sporadic transmission" category is an important alert for environmental surveillance managers to intensify and implement the direct actions of the VL Control Program in the municipality. Some of the main objectives of the VL Control Program in Brazil are to reduce the risk of transmission, identify vulnerable areas, and thus, prevent human VL cases. Therefore, early identification of epidemiological factors is a useful approach for prompting action that may prevent human VL cases within the respective municipality.

\section{CONCLUSION}

The municipality of Juatuba, Minas Gerais, fulfils all the preconditions for transmission of leishmaniasis, especially AVL, with evidence indicating a complex environment-vector-host relationship. Vectors were found in all studied areas, in addition to favorable conditions for the transmission of leishmaniasis, especially in area 2 , which presented a natural infection rate in sandflies. The presence of Lu. longipalpis and other vector species associated with canine infection, as well as the presence of Le. infantum in those vectors, indicate that the parasitereservoir-vector interface is active in the areas studied.

\section{ACKNOWLEDGMENTS}

We thank the health surveillance workers, especially in the Juatuba Zoonosis Control Sector, for their cooperation and logistical support that enabled this work. We also thank the Brazilian Ministry of Health, for providing financial support. 


\section{REFERENCES}

ALVAR, J.; VÉLEZ, I.D.; BERN, C. et al. Leishmaniasis worldwide and global estimates of its incidence. Plos One, v.7, p.1-12, 2012.

BORGES, L.F.N.M.; FREITAS, E.G.P.; FREITAS, A.C.P. et al. Prevalência e distribuição espacial da leishmaniose visceral em cães do município de Juatuba, Minas Gerais, Brasil. Cienc. Rural, v.44, p.352-357, 2014.

BRASIL. Ministério da Saúde. Secretária de Virgilância em Saúde. Guia de vigilância epidemiológica. Brasília: Ministério da Saúde. 2009. Available in: <http://portalsaude.saude.gov.br>. Accessed in: 5 Apr. 2016.

BRAZIL, R.P.; CARNEIRO, L.V.; ANDRADE FILHO, J.D. et al. Biology of Lutzomyia lenti (Mangabeira) (Diptera: Psychodidae). An. Soc. Entomol. Bras., v.26, p.191-193, 1997.

CAMARGO-NEVES, V.L.F.; KATZ, G.; RODAS, L.A.C. et al. Utilização de ferramentas de análise espacial na vigilância epidemiológica de leishmaniose visceral americana - Araçatuba, São Paulo, Brasil, 1998-1999. Cad. Saúde Pública, v.17, p.1263-1267, 2001.

DEANE, L.M.; DEANE, M.P. Visceral leishmaniasis in Brazil. Geographic distribution and transmission. Rev. Inst. Med. Trop. São Paulo, v.4, p.198-212, 1962.

DIAS, S.E.; REGINA-SILVA, S.; FRANCASILVA, J.C. et al. Eco-epidemiology of visceral leishmaniasis in the urban area of Paracatu, state of Minas Gerais, Brazil. Vet. Parasit., v.176, p.101-111, 2011.

GALATI, E.A.B.; NUNES, V.L.B.; DORVAL, M.E.C. et al. Study of the phlebotomines (Diptera: Psychodidae), in area of cutaneous leishmaniasis in the Mato Grosso do Sul State, Brazil. Rev. Saúde Pública, v.30, p.115-128, 1996.

GALATI, E.A.B.; NUNES, V.L.B.; OSHIRO, E.T. et al. New species of Phlebotominae, Lutzomyia corumbaensis, sp.n. (Diptera: Psychodidae) of the Lutzomyia cortelezzii complex. Rev. Bras. Entomol., v.33, p.765-475, 1989.
INSTITUTO Nacional Meteorologia. Monitoramento climático. Brasília: INMET, 2016. Available in: <http://www.inmet.gov.br/portal/>. Accessed in: 5 Apr. 2016.

LAINSON, R.; RANGEL, E.F. Lutzomyia longipalpis and the ecoepidemiology of American visceral leishmaniasis, with particular reference to Brazil - a review. Mem. Inst. Oswaldo Cruz, v.100, p.811-827, 2005.

LANA, R.S.; MICHALSKY, E.M.; FORTESDIAS, C.L. et al. Phlebotomine sand fly fauna and Leishmania infection in the vicinity of the Serra do Cipó National Park, a natural Brazilian heritage. BioMed. Res. Int., v.2015, p.1-9, 2015.

LARA-SILVA, F.O; MICHALSKY, E.M.; FORTES-DIAS, C.L. et al. Epidemiological aspects of vector, parasite, and domestic reservoir in areas of recent transmission and no reported human cases of visceral leishmaniasis in Brazil. Acta Trop., v.148, p.128-136, 2015.

LARA-SILVA, F.O.; MICHALSKY, E.M.; FORTES-DIAS, C.L. et al. Evaluation of chemical spraying and environmental management efficacy in areas with minor previous application of integrated control actions for visceral leishmaniasis in Brazil. Acta Trop., v.176, p.109-113, 2017.

LOPES, E.G.P.; OVIEDO-PASTRANA, M.E.; BORGES, L.F.N.M. et al. Transmission of visceral leishmaniasis in dogs in a risk area of the metropolitan region of Belo Horizonte, Minas Gerais, Brazil. Arq. Bras. Med. Vet. Zootec., v.68, p.1403-1412, 2016.

LOPES, J.V. Epidemiologia da leishmaniose visceral no município de Sabará, Região Metropolitana de Belo Horizonte, Minas Gerais, Brasil. 2014. 108f. Dissertação (Mestrado em Ciências) - Centro de Pesquisa René Rachou, Fundação Oswaldo Cruz, Belo Horizonte, MG.

LUZ, Z.M.P.; PIMENTA, D.N.; CABRAL, A.L.L.V. et al. Leishmaniasis urbanization and low diagnosis capacity in the metropolitan region of Belo Horizonte. Rev. Soc. Bras. Med. Trop.,v.34, p.249-254, 2001.

MEDRONHO, R.A.; BLOCH K.V.; LUIZ, R.R.; WERNECK, G.L. Epidemiologia. In: KALE, P.L.; COSTA, A.J.L.; LUIZ, R.R. (Eds.). Medidas de associação e medidas de impacto. São Paulo: Atheneu, 2009. p.181-191. 
MICHALSKY, E.M.; FRANÇA-SILVA, J.C.; BARATA, R.A. et al. Phlebotominae distribution in Janaúba, an area of transmission for visceral leishmaniasis in Brazil. Mem. Inst. Oswaldo Cruz, v.104, p.56-61, 2009.

MISSAWA, N.A.; DIAS, E.S. Phlebotomine sand flies (Diptera: Psychodidae) in the municipality of Várzea Grande: an area of transmission of visceral leishmaniasis in the state of Mato Grosso, Brazil. Mem. Inst. Oswaldo Cruz, v.102, p.913-918, 2007.

PUGEDO, H.; BARATA, R.A.; FRANÇASILVA, J.C. et al. HP: um modelo aprimorado de armadilha luminosa de sucção para a captura de pequenos insetos. Rev. Soc. Bras. Med. Trop., v.38, p.70-72, 2005.

RANGEL, E.F.; LAINSON, R. Flebotomíneos do Brasil. In: PIMENTA, P.F.P.; SECUNDINO, N.F.C.; BLANCO, E.E.N. (Eds.). Interação vetor-hospedeiro. Rio de Janeiro: Fiocruz, 2003. p.275-276.

RÊGO, F.D.; SHIMABUKURO, P.H.F.; QUARESMA, P.F. et al. Ecological aspects of the Phlebotominae fauna (Diptera: Psychodidae) in the Xakriabá Indigenous Reserve, Brazil. Parasit. Vectors, v.7, p.220, 2014.

TEODORO, U.; BALDUINO, J.; THOMAZSOCCOL, V. et al. Environmental sanitation and peri-domiciliar organisation as auxiliary practices for the control of phlebotomines in Paraná State, southern Brazil. Braz. Arch. Biol. Technol., v.42, p.307-314, 1999.
URSINE, R.L.; DIAS, J.V.L.; MORAIS, H.A. et al. Human and canine visceral leishmaniasis in an emerging focus in Araçuaí, Minas Gerais: spatial distribution and socio-environmental factors. Mem. Inst. Oswaldo Cruz, v.111, p.505511, 2016.

VAN EYS, G.J.; SCHOONE, G.J.; KROON, N.C. et al. Sequence analysis of small subunit ribosomal RNA genes and its use for detection and identification of Leishmania parasites. Mol. Biochem. Parasitol., v.51, p.133-142, 1992.

VIANNA, E.N.; MORAIS, M.H.F.; ALMEIDA, A.S. et al. Abundance of Lutzomyia longipalpis in urban households as risk factor of transmission of visceral leishmaniasis. Mem. Inst. Oswaldo Cruz, v.111, p.302-310, 2016.

WORLD Health Organization. Leishmaniasis: background information. Geneva, Switzerland: WHO, $1988 . \quad$ Available in: <http://apps.who.int/iris/ bitstream/10665/60369/1/WHO_LEISH_88.25.p df>. Accessed in: 10 Oct. 2016

WORLD Health Organization. Geneva, Switzerland: WHO, 2016. Available in: <http://www.who.int/

leishmaniasis/epidemic/response_more/en/index. html]>. Accessed in: 12 Oct. 2016.

YOUNG, D.G.; DUNCAN, M.A. Guide to the identification and geographic distribution of Lutzomyia sand flies in Mexico, the West Indies, Central and South America (Diptera: Psychodidae). Mem. Am. Entomol. Inst., v.54, p.881, 1994. 